University of Nebraska - Lincoln

DigitalCommons@University of Nebraska - Lincoln

Agronomy \& Horticulture -- Faculty Publications

Agronomy and Horticulture Department

1940

Deterioration of Grassland From Stability to Denudation with

Decrease in Soil Moisture

J. E. Weaver

University of Nebraska-Lincoln

Follow this and additional works at: https://digitalcommons.unl.edu/agronomyfacpub

Part of the Plant Sciences Commons

Weaver, J. E., "Deterioration of Grassland From Stability to Denudation with Decrease in Soil Moisture" (1940). Agronomy \& Horticulture -- Faculty Publications. 447.

https://digitalcommons.unl.edu/agronomyfacpub/447

This Article is brought to you for free and open access by the Agronomy and Horticulture Department at DigitalCommons@University of Nebraska - Lincoln. It has been accepted for inclusion in Agronomy \& Horticulture -Faculty Publications by an authorized administrator of DigitalCommons@University of Nebraska - Lincoln. 


\title{
DETERIORATION OF GRASSLAND FROM STABIL- ITY TO DENUDATION WITH DECREASE IN SOIL MOISTURE
}

\author{
J. E. WEAVER AND F. W. ALBERTSON
}

(WITH SEVENTEEN FIGURES)

\section{Introduction}

The great drought has now prevailed intermittently in the midwest for a period of seven years. Damage to native vegetation in I934 has been partially repaired, but further destruction has also occurred. Continued study of the shiftings in dominance among the grasses has revealed widespread losses of certain species and partial or complete replacement by others. Forbs also have greatly diminished, both in number of species and in abundance, and changes in structure of vegetation generally have been pronounced $(3,4)$. Hence it seemed advisable during 1939 to study the degree of deterioration of the grasslands, if any, from western Iowa, through eastern Nebraska and Kansas, to western Kansas where in places almost complete destruction of vegetation has occurred. This study included monthly determinations of water content of soil to the depth of root penetration of the grasses, and other major environmental factors characterizing the growing season. The rate of growth of vegetation and density of cover were determined, as well as the distribution of forbs.

Groups of prairies whose previous history was known were selected for study (fig. I). Soils were all similar, being of silt-loam texture; although those at Lincoln, Nebraska, and eastward belong to the Prairie zonal group, while those under lighter precipitation westward are Chernozems. All are of high fertility, and water is the chief limiting factor to plant growth.

${ }^{r}$ Contribution no. 12 1 from the Department of Botany, University of Nebraska. This investigation was aided by a grant to the senior author from the Penrose fund of The American Philosophical Society. 


\section{Environmental relations}

The critical environmental factors characteristic of the drought are low unevenly distributed precipitation, deficiency of soil moisture and accompanying high temperatures, high evaporation rates, and increased wind movement.

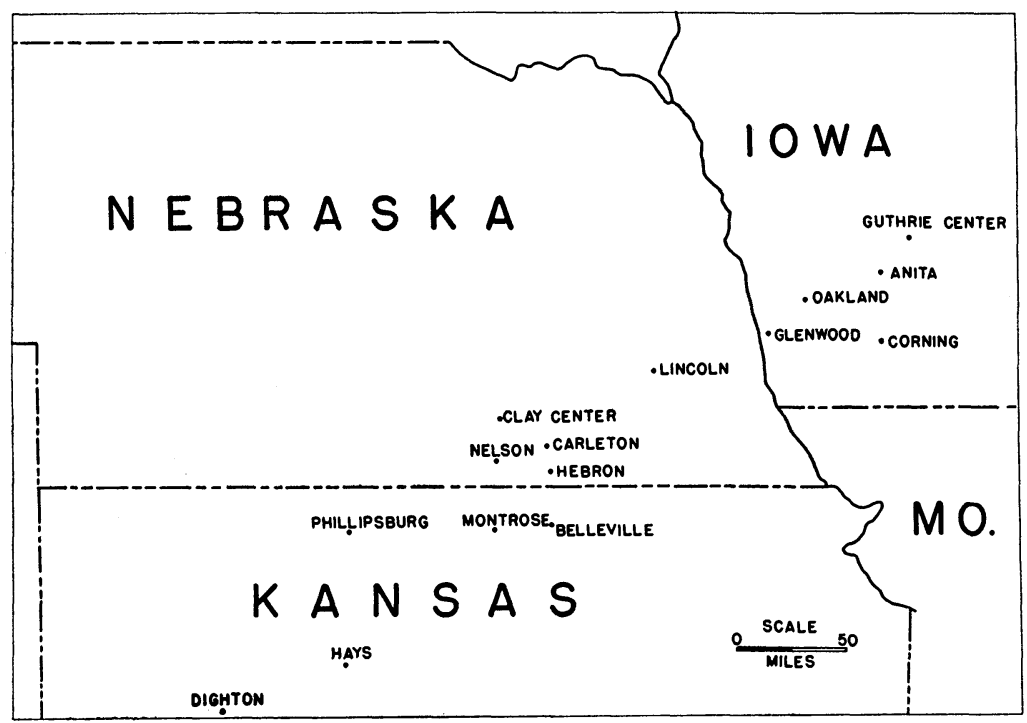

FIg. I.-Map showing the four groups of stations where studies were made in 1939 . Iowa group and Lincoln-Hebron-Nelson-Belleville group were dominated by Andropogon scoparius and A. furcatus. Agropyron smithii was dominant at Clay CenterCarleton-Montrose group, and Bouteloua gracilis and Buchloe dactyloides at the three most southwesterly stations.

\section{Precipitation AND WATER CONTENT OF SOIL}

Stations for water-content sampling were selected with reference to typical and relatively uniform composition of vegetation. In each group of stations were included various gentle slopes and nearly level uplands, where water content of soil depended entirely upon the precipitation in that area. Samples were secured regularly near the middle or latter part of each month from April to August, inclusive.

At the five stations in Iowa, where the mean annual precipitation ranges from 29.5 to 33.7 inches, rainfall during the several months 
was sufficient to keep both soil and subsoil constantly moist to a depth of 6 feet at least (fig. 2). In April, at all stations the surface 24 inches of soil had 10-20 per cent or more moisture available for growth, and the deeper soil $2-$ ro per cent or more. ${ }^{2}$ During the entire growing season, soil moisture depleted by the growing vegetation was restored more or less regularly and completely. To a depth of 24 inches, the available supply ranged continuously between 2

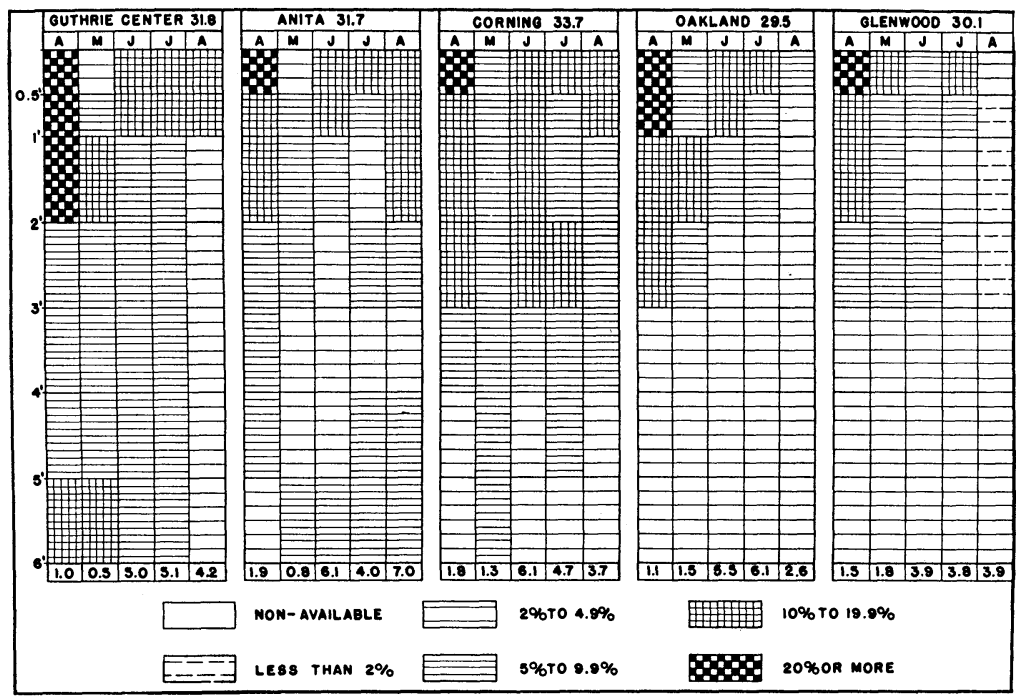

FIG. 2.-Available soil moisture to depth of 6 feet at the five Iowa stations during 1939. Mean annual precipitation at each station follows the name, and total current monthly rainfall is given at the foot of each column.

(but usually 5) and Io per cent or more. A single exception occurred at the most westerly station (Glenwood), where in August water content was reduced to a minimum of less than 2 per cent. Water in the deeper soil was also always available, usually in the amount of $2-5$ per cent or more. This moderate water content of soil resulted not only from the rather regular and well distributed rainfall, but also from its ready entrance into these silt-loam soils, which were kept in a porous, water-receptive condition by the continuous cover of grass.

2 Total water content of soil minus the hygroscopic coefficient (which was determined for each soil depth at each station) is designated as water available for growth. The hygroscopic coefficients, with few exceptions, ranged between 9.I and I 2.9 per cent. 
The mean annual rainfall at the second group of stations varies from 26.2 to 27.9 inches. Precipitation is sufficient, if well distributed, to keep the soil continuously moist under a cover of grassland, but this was a season of drought. Rainfall of June alone was equal to (or slightly below) the normal at all stations in this group (fig. 3 ). Early spring sampling showed an available water supply of $2-20$ per cent or more in the surface 24 inches, except at the Kansas station

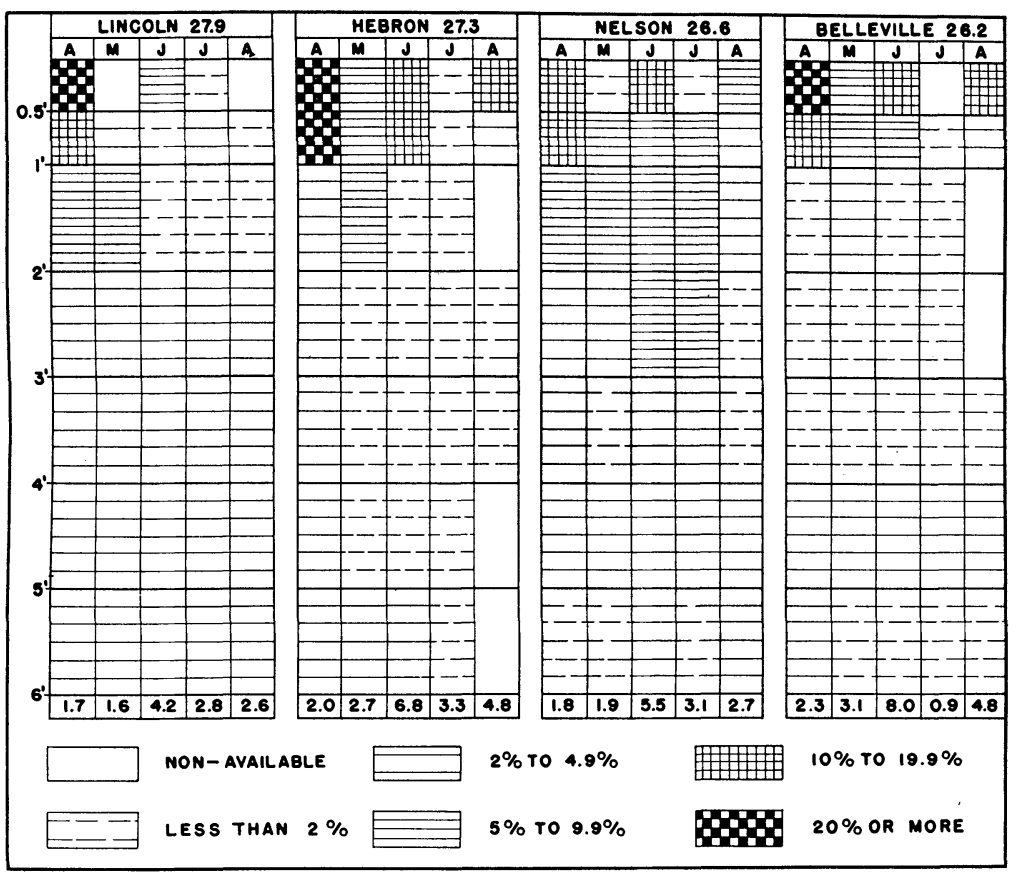

FIG. 3.-Available water content of soil and mean annual and current monthly precipitation at Nebraska-Kansas bluestem stations in I939.

(Belleville) where the second I. -inch level had less than 2 per cent. The subsoil to 6 feet had consistently 2 per cent or more of available water, except at three levels at two stations where it was less than 2 per cent (fig. 3 ). The surface 24 inches maintained a good water content continuously at only one station (Nelson); at the others it was reduced to the point of nonavailability at some level one or more times, and at several samplings to less than 2 per cent. In the subsoil at Lincoln a small supply (2-4.9 per cent) was continuously available to $6 \mathrm{feet}$; at the other stations available water was fre- 
quently reduced to less than 2 per cent, and at some periods none was available at certain levels.

While reduction in water content was brought about by a considerably depleted plant cover, much bare ground was also present. This decreased the efficiency of absorption of water to a considerable degree and promoted greater loss by runoff. Very numerous experiments, at practically all of the stations in the second and third groups, showed that within the same square meter water penetrated one and a half to two or even three times as rapidly where grasses still clothed the soil as where the ground was bare.

The three stations, Clay Center, Carleton, and Montrose, form a natural grouping, despite the fact that the mean annual precipitation at Carleton is slightly above that of two in the preceding group (fig. 4). The dominant vegetation at these stations is western wheat grass (Agropyron smithii) and not bluestems (Andropogon scoparius and $A$. furcatus), as at all the preceding prairies. Hence an important factor affecting the early exhaustion of soil moisture was, unlike that of bluestems, the very early and rapid growth of the wheat grass.

A good available water content occurred in the surface foot in April (Io to more than 20 per cent). Available water was sufficiently replenished at Carleton so that at least very small amounts continuously occurred in the first foot, but at the other stations complete exhaustion over long periods was repeatedly found. At I-2 feet in depth, small amounts of water were available except in August at Carleton, but moisture was never available at this level at Montrose. Below 2 feet, no water was available for growth at any level of sampling after April, except less than 2 per cent at $5^{-6}$ feet depth at Carleton and similar small amounts (or none) at Clay Center.

These prairies had not only suffered greater losses of plant cover by previous drought than the preceding group, but also a rather complete change in plant population. This resulted in part from a cover of dust of variable thickness which clogged the soil pores so effectively that much of the torrential rainfall never entered the soil but was lost as runoff. Moreover, it has been found that wheat grass furnishes only poor protection to soil from surface puddling 
when water falls upon it. Compared with the rate of penetration in adjacent, small, relict areas of bluestems, the period required for the entrance of similar amounts of water (as in light to moderate showers) is one and a half to two times as great.

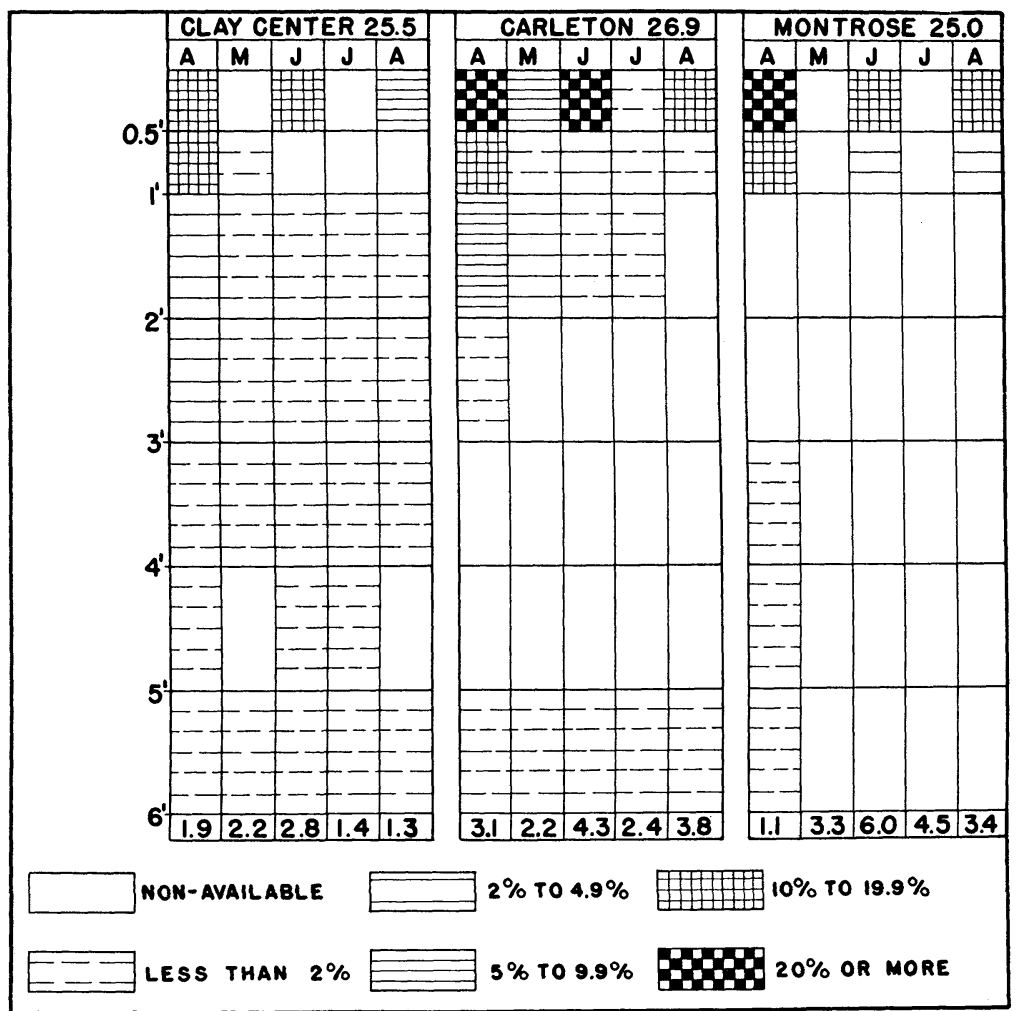

FIG. 4.-Mean annual precipitation, current monthly precipitation, and available soil moisture at Nebraska-Kansas wheat-grass stations in 1939.

The last group of stations has a decidedly lower mean annual precipitation, I8.9-23.3 inches, than any of the preceding (fig. 5). The mixed prairie grassland has here been more or less completely reduced, either by the recent drought (Phillipsburg) or by long continued grazing and drought (Hays and Dighton), to a short-grass plains disclimax. On each prairie enough silt has been deposited as dust to seal the soil so effectively that runoff has been greatly in- 
creased. It was further accelerated by the small amount of vegetative cover and consequent lack of much obstruction to water movement. Thus, despite the rather high rainfall of June, the surface soil alone was moistened. Usually in this more arid region much of the precipitation is of low efficiency, because it falls either as torrential showers with high runoff or in many small showers followed by

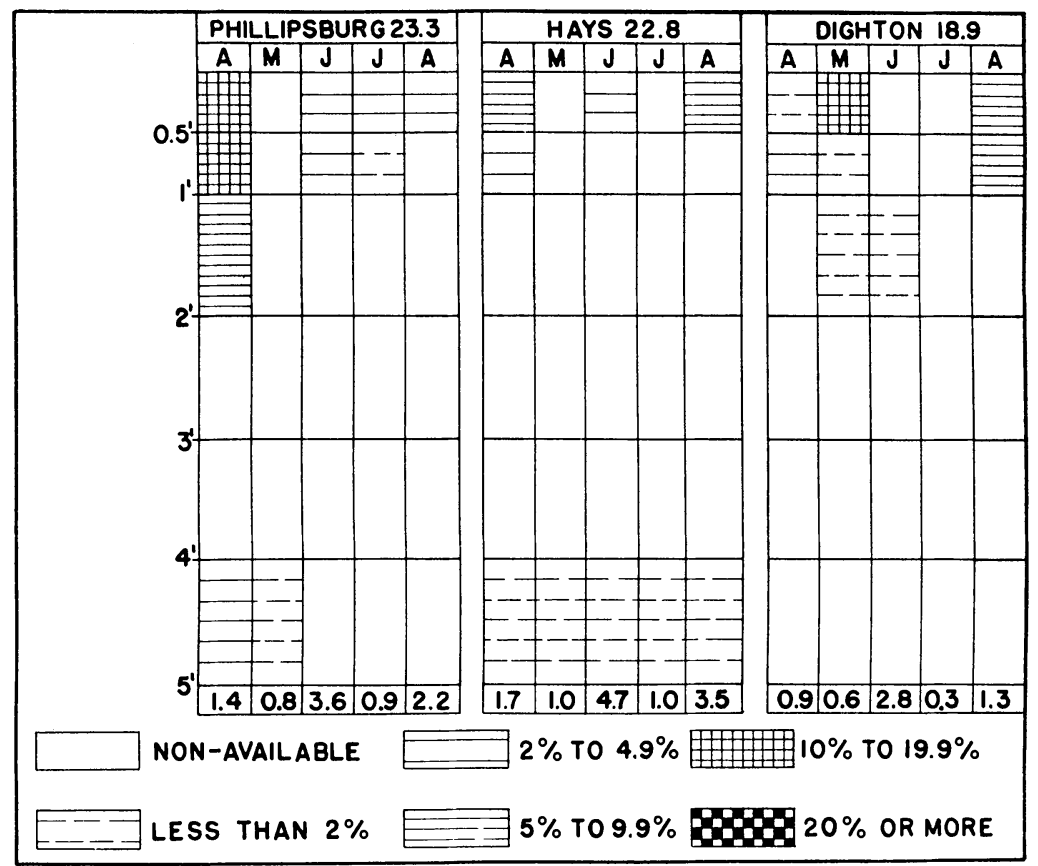

FIG. 5.-Chart showing relatively small amounts of water available for growth of vegetation in western Kansas and lack of subsoil moisture in I939.

bright sunshine and often by high winds; hence the water is soon lost from the soil by evaporation. For example, the 4.7 inches of rain in June at Hays fell on thirteen different days. Only four of the rains exceeded 0.3 inch in amount and the heaviest for any day was I.5 inches.

The surface foot of soil was moist (mostly from melting snow) in April, but only slightly so at the most westerly (Dighton) station. At various times throughout the summer no surface soil moisture was available for growth. The deeper soil, with rare exception, had 
no available water. There was no reserve, even in early spring. At Hays it seems that a small amount of residual moisture remained unused at the 5 -foot depth.

The charts present an accurate general picture of water content of soil. Weekly determinations add but little information to the general sequence. At Hays, for example, weekly samplings showed that during the first three days of May small amounts of water were available in the surface 6 inches. Water was also available the first five days of July and unavailable the last four days in August. At the second 6-inch level it was available in small amounts in the first week of May. Otherwise the weekly data conform entirely with the chart.

Thus while the grasslands of Iowa had an abundant to moderate but continuous supply of available soil water, those in the second group had-after early spring - only a low supply and were repeatedly threatened with drought. At the third lot of stations, available subsoil moisture was the exception; at Carleton the surface foot was usually moist, but complete exhaustion occurred repeatedly in the other prairies. Water was available only in the upper soil at the most westerly stations and only at two or three periods during the growing season.

Temperature, EVAPORATION, AND WIND

Mean temperatures for April were practically normal, and only $2.7^{\circ} \mathrm{F}$. (or less) higher in the most southerly group of stations $\left(53.7^{\circ}\right)$ than in the eastern or two central ones. They varied less than $\mathrm{I}^{\circ}$ among groups during May, but at all stations they were about $5^{\circ}-8^{\circ}$ higher $\left(68^{\circ} \mathrm{F}\right.$.) than normal. A difference of only $2.5^{\circ}$ between the lowest and highest average temperatures occurred in June, the highest average $\left(75.2^{\circ}\right)$ being recorded in west-central Kansas. At all stations, temperatures were only $2^{\circ}-4^{\circ}$ above normal. During July, temperatures from Iowa to western Kansas ranged from $77.9^{\circ}$ through $82.8^{\circ}$ to $84.0^{\circ}$. They were approximately $3^{\circ}-6^{\circ}$ higher than normal, the increase being slightly the greatest in western Kansas. August was cooler, mean average temperatures being $72.0^{\circ}, 75.6^{\circ}$, and $77.9^{\circ}$ in the preceding sequence. Variation at any station above or below the normal did not exceed $2^{\circ}$.

Maximum temperatures during periods of stress were neither so 
high nor of so great duration as during 1934 or 1936. The writers believe that high temperatures in grasslands have not been the direct cause of death of plants, but that they are merely one of several factors which intensified drought. Death due directly to drought resulted from lack of water. Where a water supply was artificially maintained for native species, no injury has been found.

Water loss as measured by rate of evaporation was much greater at the westerly stations than at those eastward. During April and May it was $39^{-} 5^{\text {I }}$ per cent higher at Hays than at Lincoln. In June and July it was about twice as great at Hays, the difference in rate decreasing to 63 per cent in August. The lowest loss at Hays was 8.9 inches from a free water surface in April; the highest 20.6 inches in July. ${ }^{3}$

Comparison of the average daily losses from May to August inclusive during the extremely dry, hot summer of 1934 and that of I939 is pertinent. These were measured by white, spherical, porous cup atmometers. Evaporation in I 934 was 82 cc., in I 939 only 49 cc. During the hottest month of I939 (July) the average daily loss was $48 \mathrm{cc}$., compared with $96 \mathrm{cc}$. in I934. Compared with evaporation losses during 1933 (just preceding the severest year of drought), weekly averages were higher only three times. During the period of greatest stress (third week of July), however, losses were $88 \mathrm{cc}$., twice as great as during the same period in 1933 .

Wind movement increases westward. During April, I939, it was about twice as great at Hays as at Lincoln. In May and June it was about three times as great, in July three and a half times, and in August there was more than three times as much wind movement westward. From April to August inclusive it totaled over 28,000 miles at Hays, at Lincoln about $10,000 .^{3}$ Wind is increasingly detrimental to vegetation westward, not only because of the damage done by wind-carried dust but also because of frequent high velocities immediately following showers. This increases both evaporation and transpiration, which in turn accelerate the depletion of soil moisture.

While neither wind movement nor evaporation losses were as great as during certain other drought years, at most stations at

3 Data from U.S. Department of Agriculture, Weather Bureau. 
least they were considerably greater than normal during the predrought period. Loss of vegetative cover increased wind movement near the soil and greatly accelerated direct loss of soil moisture by evaporation. Had the soil provided ample water for absorption, however, it seems certain that vegetation would have suffered little, even under these conditions of somewhat increased temperatures, greater stress of evaporation, and increased wind movement.

\section{Previous deterioration of plant cover}

The Iowa prairies had not been affected as regards change of structure by the great drought of 1934 or subsequently. An exception was some death on the drier slopes at Corning, but complete recovery had occurred by 1939 (3). In spring, following the preceding mowing in fall, the soil at all the stations was completely obscured by stem bases and a continuous cover of fallen debris a few millimeters in thickness. There was no bare ground (figs. 6, 7). Numerous lichens and mosses were found on the damp spongy earth between the tufts of sod. By midsummer the tall dense cover of vegetation, with a wonderfully developed understory and an abundance of forbs overtopping the grasses, revealed the prairies as of old (5). At no time during the entire growing season was plant development retarded by drought.

Deterioration of the prairies of Nebraska during the drought of I934 and the results of the drought in both Nebraska and Kansas during the following year have been described $(6,3)$. With successive dry years further deterioration had occurred (4). At the second group of stations in the spring of I939, much soil was bare. Soilsampling stations were selected in the more stable portions of each of the four prairies where the cover of bluestems, although greatly thinned, remained intact. A chief change was an increase of other grasses, especially Bouteloua curtipendula. Widely spaced bunches and tufts of grasses with much bare soil, almost without protecting debris, were the characteristic features (figs. 8, 9). The basal cover had been reduced to two-thirds to one-half its former area. The ground layer of low-growing species and of lichens and mosses in spring had practically vanished. The remaining vegetation produced much less debris. The lack of moisture and shade caused it to 

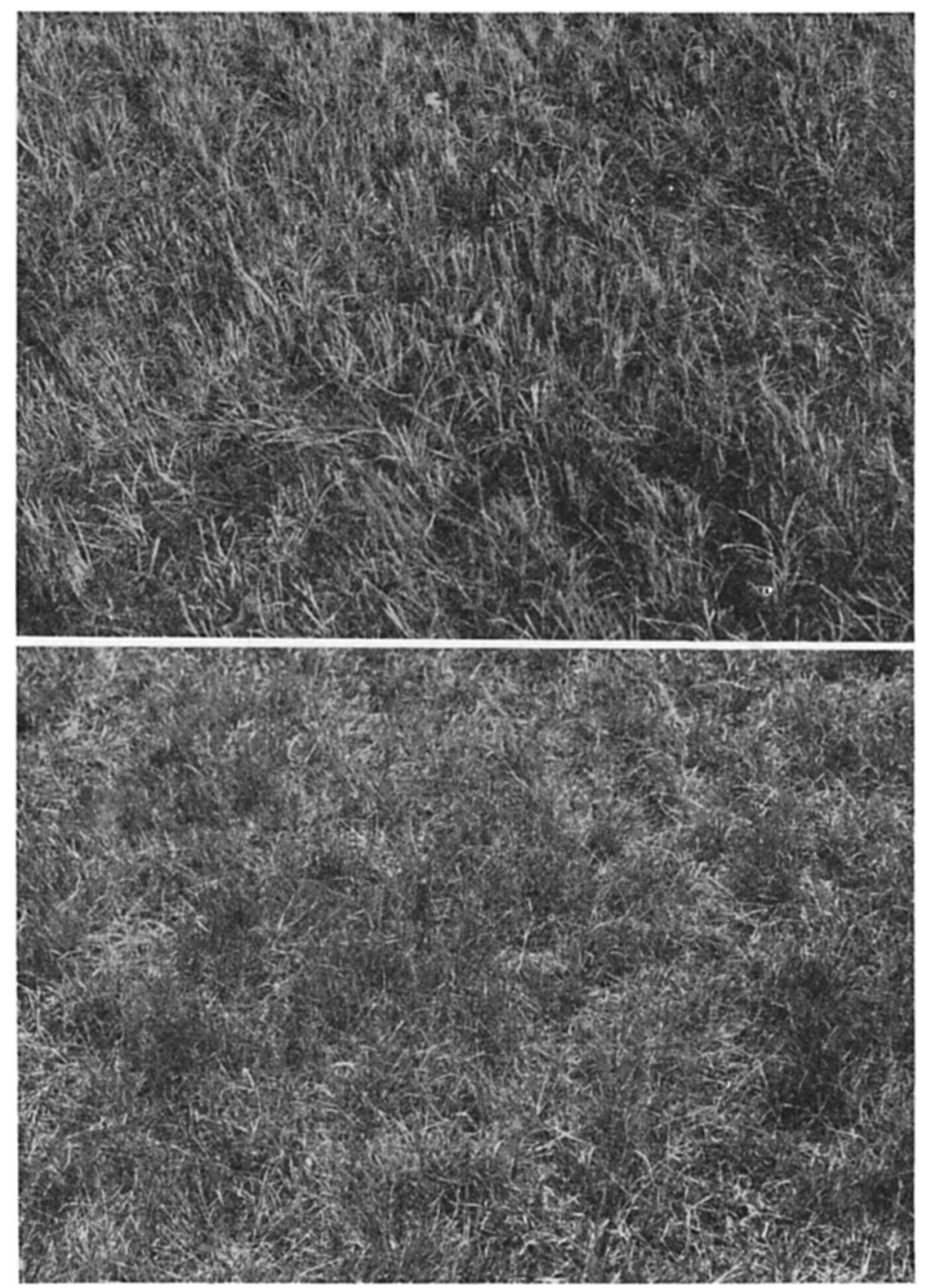

Figs. 6, 7.-Fig. 6 (above), basal cover at Guthrie Center, Iowa, late in April, I939. The bluestems, etc., were mowed late in fall of preceding year, yet the leafy stem bases and fallen debris completely conceal the soil. Fig. 7 (below), similar view at Oakland, Iowa, April 2r. Note complete cover of dormant grasses and leaf mulch. 

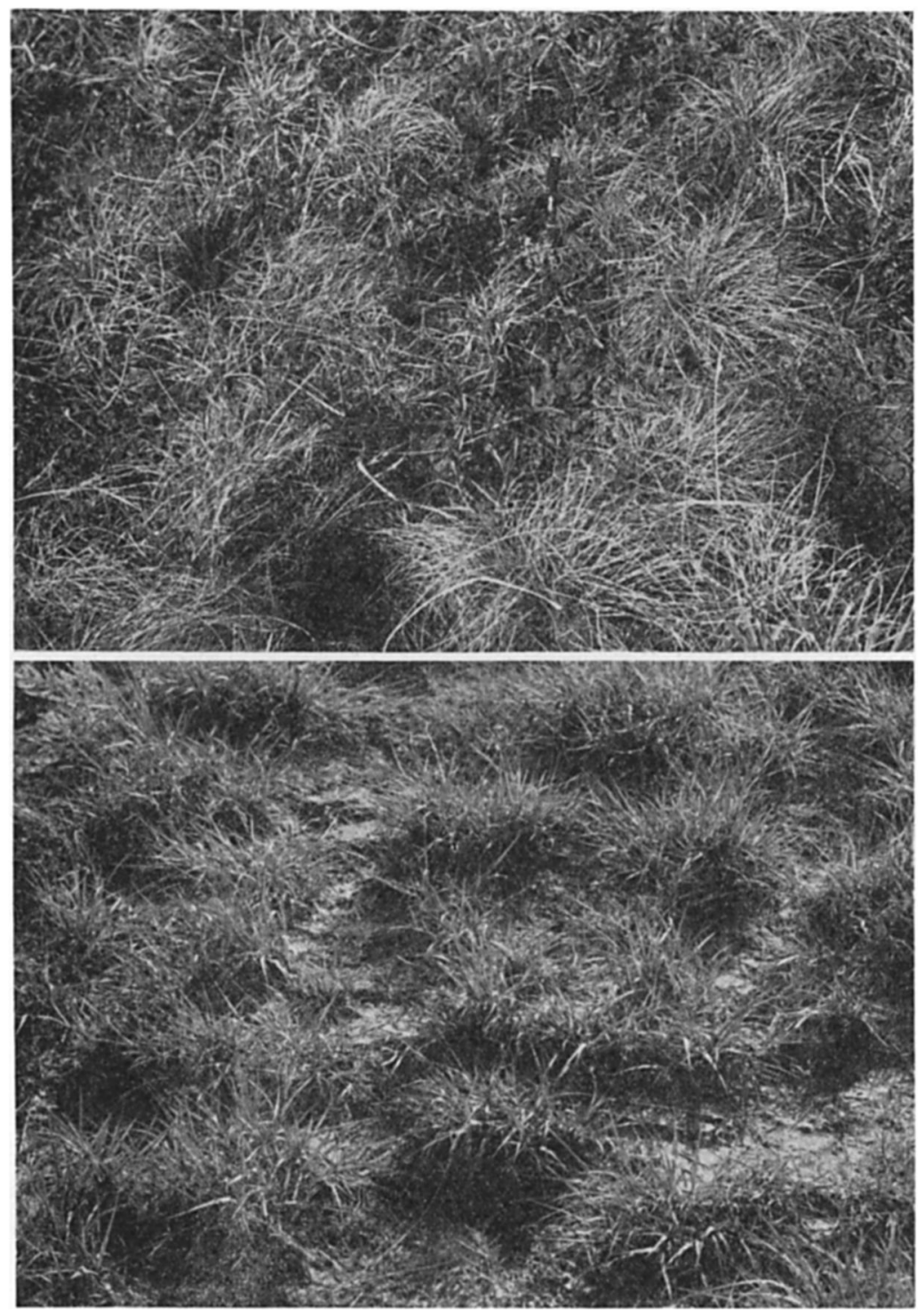

Figs. 8, 9.-Fig. 8 (above), basal cover of little bluestem and other grasses which had made some fall growth after early mowing in autumn of 1938 . Soil between bunches of grass is almost bare. Photographed Lincoln, Nebraska, April 29, 1939. Fig. 9 (below), similar view at Nelson on June 16, 1939. Widely spaced bunches and bared soil permit much loss of precipitation by runoff. 
shrivel and dry, and high winds carried it away, leaving the ground quite bare. Each successive year of drought had further reduced a once abundant growth of forbs, until the grasses almost alone constituted the mid-layer, which was overtopped sparingly by small remnants of the once abundant taller forbs.

Great modifications, involving an almost complete change in the species of dominant grasses, had occurred at the three more xeric stations-Clay Center, Carleton, and Montrose. The bluestems had been all but exterminated by drought and deposits of dust, the Carleton prairie being least affected by dust burial. A wave of Agropyron smithii had swept over these prairies, taking rather complete possession, but this grass was being partly replaced by rapid spread of Bouteloua curtipendula (2). Sufficient moisture had not been available for the sod-forming wheat grass to aggregate densely. Between the widely spaced stems much unoccupied soil occurred, other plants had nearly all died, litter was scarce, and bare ground formed a continuous pattern everywhere.

Drought and dust had caused greater deterioration at the western Kansas stations than in any other group. The ungrazed prairie at Phillipsburg had lost nearly all its mid grasses (except $B$. curtipendula) and was largely converted into an open stand of the short grasses-B. gracilis and Buchloe dactyloides (fig. 10). Subsequently side-oats grama (Bouteloua curtipendula) had increased greatly. Only a single layer of vegetation remained, however, since these grasses alternated and did not intermix, while forbs occurred only sparingly. Where B. curtipendula grew, only to per cent of the soil was occupied, the wide spacing being an adaptation to drought. The patches of short grasses were so widely spaced that they probably occupied only about ro per cent of the total of the remaining surface, since many irregular areas of a few square feet to a few square yards were entirely bare.

The two short grasses in the moderately grazed range at Hays were formerly intermixed almost equally to form a basal cover of approximately 85 per cent $(\mathbf{I})$. This had been reduced by a light cover of dust and drought to only i6 per cent (fig. I I). In 1939, blue grama (Bouteloua gracilis) formed three-fourths of the vegetation, buffalo grass (Buchloe dactyloides) having suffered the greater losses. 

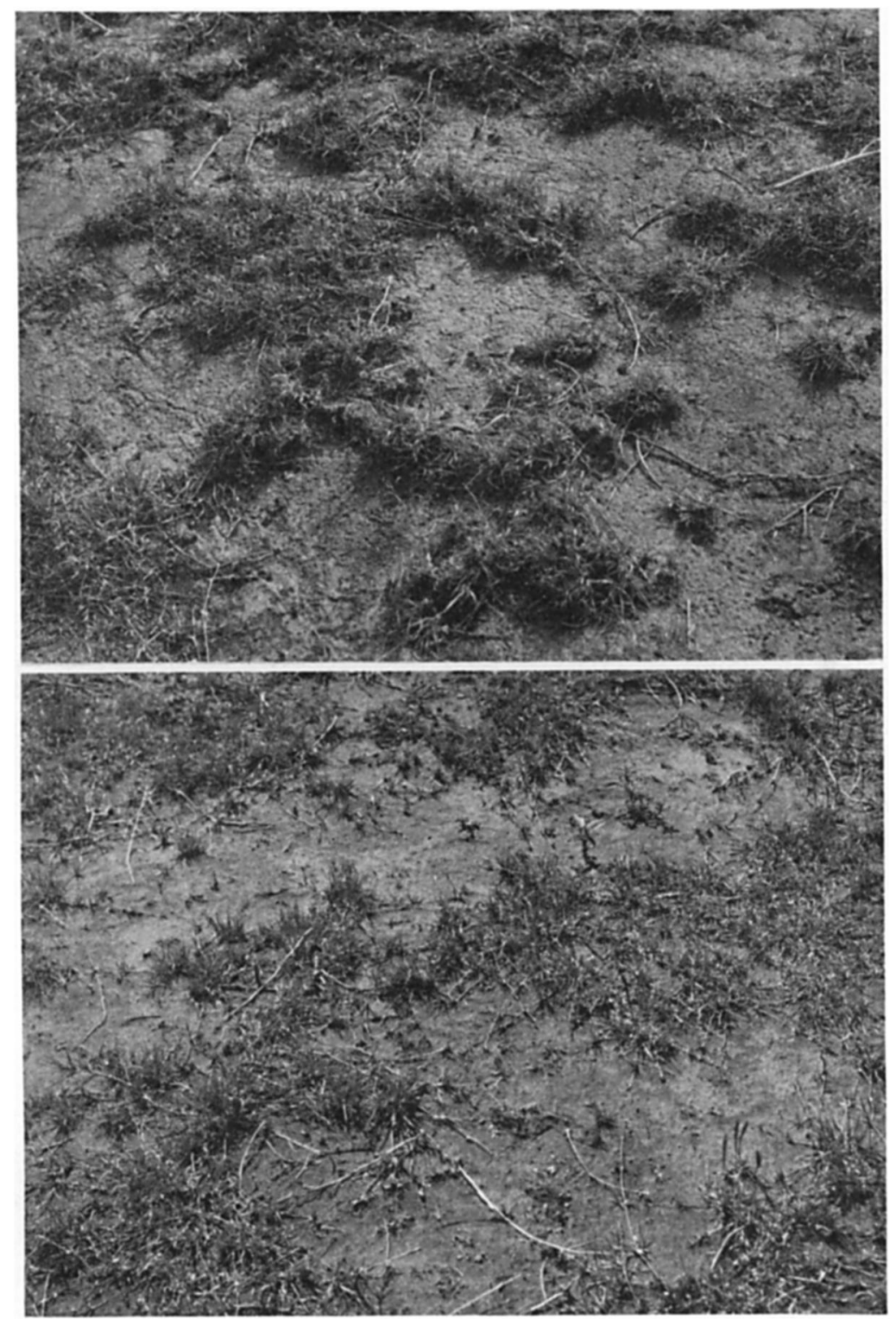

FIGS. IO, II.-Views of short grasses showing conditions of vegetation at most westerly group of stations early in June, r939. Fig. ro (above), nearly pure Boutelioua gracilis in lightly grazed range representative of this type at Phillipsburg, Kansas. Fig. I I (below), Buchloe dactyloides in well kept pasture, illustrative of depletion of cover near Hays, Kansas. 
Little bluestem (Andropogon scoparius), other mid grasses, and most of the forbs had succumbed to drought.

Blue grama and buffalo grass, in approximately the proportions of $3: \mathrm{I}$, constituted practically the entire cover of $\mathrm{I} 2-\mathrm{I} 5$ per cent at Dighton. This prairie was also grazed, as are practically all the upland midwestern grasslands, since the forage is usually too short to cut for hay. At all three stations, plants of the lower layer had all but disappeared, and any debris from the scanty vegetation was swept away by high winds, leaving the surface nearly bare (figs. I 2, I3).

Thus the preceding years of deficient moisture, great dust storms, and other unfavorable environmental conditions, while scarcely extending to the prairies of Iowa, had an increasingly deleterious effect toward the central area of greatest damage in western Kansas.

\section{Plant development in relation to drought}

Growth in spring was delayed at the Iowa stations because of late heavy snow. For most species it began late in April and progressed steadily, uninterrupted by drought at any time during the summer. A sprinkling of 2-5 per cent of Poa pratensis throughout and its blossoming at a height of $10-\mathrm{r} 2$ inches in May were evidence of the mesic conditions that prevailed. Height growth of the foliage of bluestem grasses was complete late in July, when a level of $15^{-20}$ inches was attained; after this flower stalks began to develop. The yield of forage was about normal, one to one and a half tons per acre.

Early spring growth was about normal at the second group of bluestem stations. The prairie vegetation was much less luxuriant because of the severe thinning of the grasses and the fact that the bunches were poorly filled with stems, both effects of the preceding drought. In Iowa, for example, a given basal area of little bluestem was $75^{-9} 9$ per cent occupied with leafy stems, but in this group the space was usually only one-third to one-half filled. Moreover the understory was represented by mere fragments or none of the usually widely distributed Viola pedatifida, Antennaria campestris, Astragalus crassicarpus, Sisyrinchium angustifolium, and the rosettes of Hieracium longipilum, Erigeron ramosus, and others. Precipita- 

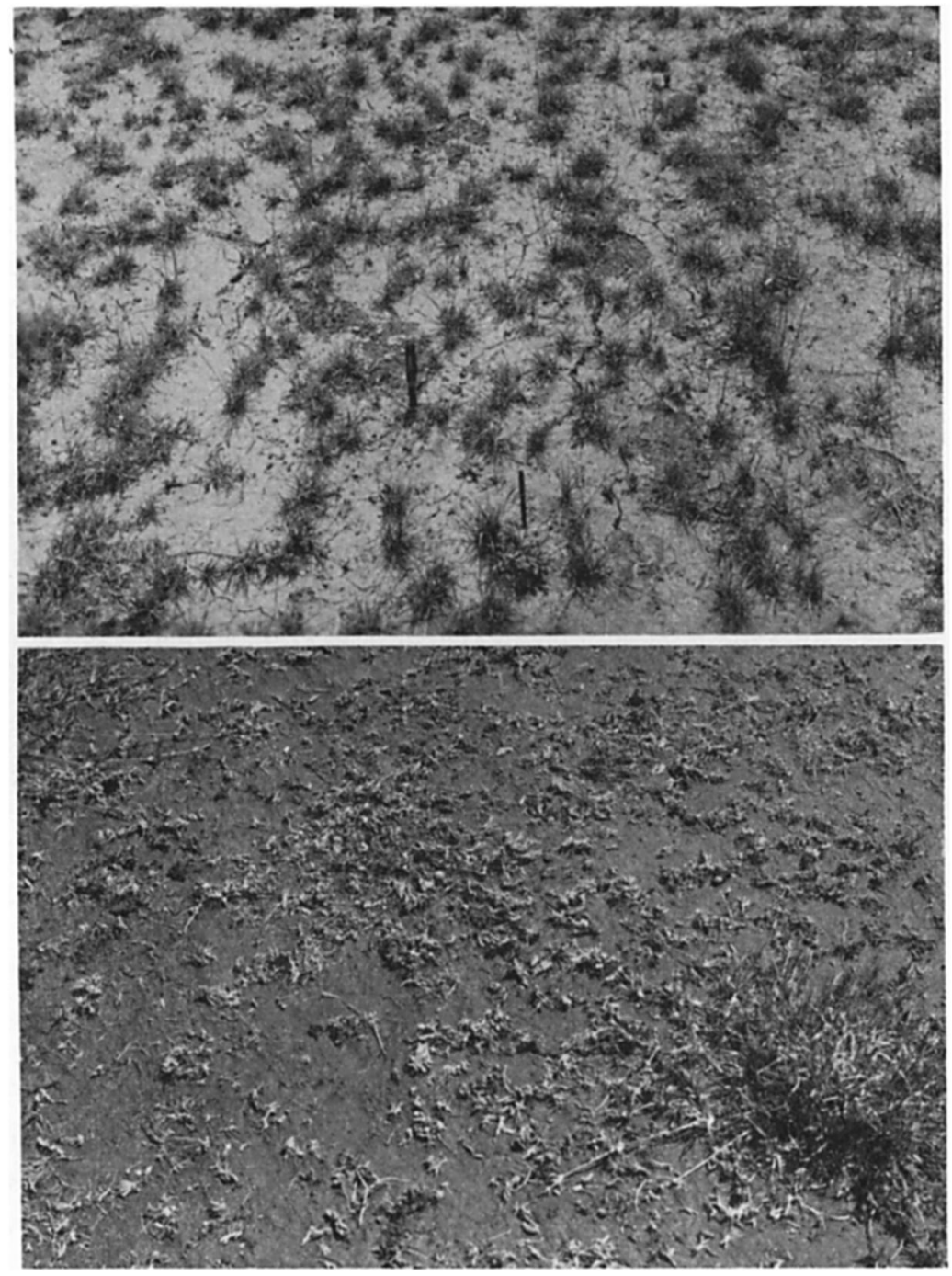

FIGS. 12, 13.-Fig. I 2 (above), typical ground cover at Dighton, Kansas, August, 1939, on lightly grazed range. Bouteloua gracilis and Buchloe dactyloides constituted nearly all the scanty vegetation, but Malvastrum coccineum and a few other xeric forbs occurred. Eighty-eight per cent of soil is bare. Fig. 13 (below), almost complete loss of vegetation by burial with dust, which wind has now swept away, leaving dead bases of short grasses as evidence of formerly good cover. Photographed Sharon Springs, Kansas, June 2, 1939 . 
tion in May was deficient. Grasses of early growth, especially Stipa spartea and Agropyron smithii, soon exhausted their water supply, and late in the month were wilted and the leaves much discolored. Stipa produced very little seed, and flower stalks of Koeleria cristata were short. Abundant rainfall in June permitted normal development of the vegetation. Drought prevailed at several periods in July, with temporary revival of growth following showers. By midJuly both andropogons were wilting at most stations and many leaves were dead and brown. Pronounced drought injury was evident during August. The grasses dried more or less completely, after producing the reddish or brownish colors of late autumn, although some new greening of basal leaves occurred following showers in September. Flower stalks were not produced by the bluestems, except at Nelson, which had the best water supply (fig. 3). The formerly pronounced seasonal aspects were poor in spring and early summer, and there were none thereafter. Yield of forage was light, only one-third to one-half ton per acre.

Growth at the third group of stations (Clay Center-CarletonMontrose) began about a month earlier than at the preceding one, since the controlling species is the early starting Agropyron smithii. Its dominance followed the death, by drought and (in part) burial by dust, of the bluestems. Loss of the bluestems was accompanied by death of a considerable portion of the population of forbs and other grasses. As a result of the lighter rainfall and the earlier absorption of soil moisture, growth was poor even in early summer. The spring aspect was poorly developed and lack of seasonal aspects characterized the remainder of the year. The wheat grass was 5 inches tall by April I2, at a time when the prairies were dry and the old foliage sprinkled with dust. Drought in May caused the leaves to roll tightly, and growth temporarily ceased. During June, when blossoming normally occurs, the foliage level was only 7 -14 inches high and flower stalks were few or none, except at Montrose where a scanty crop was developed. During the remainder of the summer, the stems and leaves were dry and the intermixed side-oats grama - and even the blue grama-failed to produce flower stalks. No plant was in blossom; indeed the entire landscape presented no green color. An exception occurred at Carleton, where a good crop 
of short flower stalks was produced by side-oats grama in July. At Montrose, a prairie fire burned clean everything above ground over half the area the first week in July. Of the few scattered forbs, all but those of spring failed to flower; grasses developed so poorly that the crop of hay was too scanty to warrant cutting.

Growth occurred only intermittently at the short-grass stations, since there was no reserve moisture and vegetation depended entirely upon the light current precipitation. A few vernal species with large storage organs, especially Anemone caroliniana and Allium nuttallii, grew in response to moisture furnished by melting snow, as did certain annuals, notably Plantago spinulosa, P. purshii, Lepidium densiflorum, and Hordeum pusillum. Few annuals, including Salsola pestifer, developed beyond the seedling stage or attained a height of more than $\mathrm{I}^{-} 3$ inches. Even the perennials with food reserves usually failed to produce flower stalks; only a few windflowers, for example, partly unfolded their blossoms on dwarfed stems which dried with the exhaustion of available water.

Rains of late May or early June promoted ephemeral growth of the dusty, dry short grasses, which was soon terminated by midsummer drought. The prairies were sere and brown until once again the surface soil was moist in August. Then stolons of buffalo grass spread laterally $5^{-10}$ inches before the moisture was exhausted, the roots at the nodes becoming successively shorter and more subject to death from drying as the distance from the parent plant increased. Where some protection was afforded from too rapid drying, as about the bunches of cacti, blue grama grass put forth flower stalks and blossomed in late fall. But later examination revealed that few viable seeds were matured. The dwarfed, most xeric forbs grew precariously, with little or no blooming.

Thus, except for sporadic greening, these prairies were mostly in a condition of drought dormancy, with grass leaves rolled or folded. The short grasses, exclusive of the few flower stalks, were only 2-3 inches tall. In addition to light grazing by cattle (except at Phillipsburg), the leaf tips of the short grasses were often removed by grasshoppers, which occurred plentifully throughout the entire growing season, frequently at the rate of 6-I5 per square foot. Little bluestem, wire grasses (Aristida spp.), and other mid grasses having 
been killed by drought, the very open growth of short grasses alone partially covered the soil, except at Phillipsburg where short grasses alternated with side-oats grama. The impress of drought prevailed at all times. In fact, the much depleted cover, rather than being restored, apparently suffered further deterioration.

\section{Grasses and forbs at the several stations}

A census was made at each station, where soil samples were taken, of all species occurring within a radius of 100 feet. The lists of grasses and sedges and of forbs at the Iowa stations are shown in table I. There are fifteen species in the first group. The forbs varied in number from thirty-seven to forty-eight at the individual stations and totaled sixty-five species. There were nineteen species of grasses at the Lincoln group of stations. Number of species of forbs varied from nine to nineteen and totaled thirty-three (table 2). In the group of wheat-grass prairies, the grasses and sedges were reduced to nine species. Species of forbs varied from eight to fifteen, with a total of twenty-one (table 3 ; figs. I4-I7).

The forbs occurring at the three most westerly stations were few in number. Many less xeric species, common before the drought, were not found. The most evenly (although sparingly) distributed at the three sampling stations were Malvastrum coccineum and Sideranthus spinulosus. Kuhnia glutinosa, Psoralea tenuiflora, Liatris punctata, and Cirsium undulatum were found less abundantly, each at least at two of the three stations. Allionia linearis, Allium nuttallii, Anemone caroliniana, Lygodesmia juncea, and Opuntia humifusa occurred in the sampling area of at least one station. To this list of eleven perennial species must be added a half dozen (mostly native) annuals, previously mentioned, and the dominants Bulbilis dactyloides and Bouteloua gracilis; also at one station, B. curtipendula. Thus both reduction in number of species and sparseness of individuals toward the "dust bowl" were emphasized. Here, indeed, the web of life is stretched thin to cover the barren ground.

Increase in number of grasses from fifteen to nineteen from Iowa to Nebraska resulted from the gain of six xeric species (Agropyron smithii, two species of Bouteloua, Buchloe dactyloides, Festuca octoflora, and Sporobolus asper), but also included the loss of two (Elymus 
TABLE 1

BLUESTEM PRAIRIES IN IOWA, SHOWING SPECIES OF GRASSES, SEDGES, AND FORBS AT EACH SAMPLING STATION: I, GUTHRIE CENTER; 2, ANITA; 3, CORNING; 4, OAKLAND; AND 5, GLENWOOD

\begin{tabular}{|c|c|c|c|c|c|c|c|c|c|c|c|}
\hline \multirow{2}{*}{ Species } & \multicolumn{5}{|c|}{ Stations } & \multirow{2}{*}{ SPECIES } & \multicolumn{5}{|c|}{ Stations } \\
\hline & I & 2 & 3 & 4 & 5 & & I & 2 & 3 & 4 & 5 \\
\hline Andropogon furcatus. & $\sqrt{ }$ & $\sqrt{ }$ & $\sqrt{ }$ & $\sqrt{ }$ & $\sqrt{ }$ & Euphorbia corollata.. & $\sqrt{ }$ & $\sqrt{ }$ & $\sqrt{ }$ & $\sqrt{ }$ & $\sqrt{ }$ \\
\hline A. scoparius ........ & $\sqrt{ }$ & $\sqrt{ }$ & $\sqrt{ }$ & $\sqrt{ }$ & $\sqrt{ }$ & Fragaria virginiana. . & $\sqrt{ }$ & $\sqrt{ }$ & $\sqrt{ }$ & & $\sqrt{ }$ \\
\hline Bouteloua curtipendula. . . & $\sqrt{ }$ & $\sqrt{ }$ & $\sqrt{ }$ & $\sqrt{ }$ & $\sqrt{ }$ & Gentiana puberula... & $\sqrt{ }$ & . & $\sqrt{ }$ & $\sqrt{ }$ & $\sqrt{ }$ \\
\hline Carex festucacea........ & $\sqrt{ }$ & $\sqrt{ }$ & & $\sqrt{ }$ & $\sqrt{ }$ & Helianthus rigidus. . . & $\sqrt{ }$ & $\sqrt{ }$ & $\sqrt{ }$ & $\sqrt{ }$ & $\sqrt{ }$ \\
\hline C. pennsylvanica. . & $\sqrt{ }$ & $\sqrt{ }$ & $\sqrt{ }$ & & $\sqrt{ }$ & Heuchera hispida. . . . . & $\cdots$ & $\cdots$ & $\sqrt{ }$ & . . & \\
\hline Elymus canadensis. . & $\sqrt{ }$ & $\sqrt{ }$ & $\sqrt{ }$ & $\sqrt{ }$ & $\sqrt{ }$ & Hieracium longipilum. & $\sqrt{ }$ & $\ldots$ & $\sqrt{ }$ & . & $\sqrt{ }$ \\
\hline Eragrostis spectabilis. & $\sqrt{ }$ & & $\ldots$ & $\sqrt{ }$ & $\sqrt{ }$ & Houstonia angustifolia. & . . & & $\sqrt{ }$ & & \\
\hline Koeleria cristata....... & $\sqrt{ }$ & $\sqrt{ }$ & $\sqrt{ }$ & $\sqrt{ }$ & $\sqrt{ }$ & Kuhnia glutinosa...... & $\sqrt{ }$ & & $\sqrt{ }$ & $\sqrt{ }$ & $\sqrt{ }$ \\
\hline Muhlenbergia cuspidata. . & $\ldots$ & & $\sqrt{ }$ & $\sqrt{ }$ & 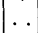 & Lepachys columnaris. . & $\sqrt{ }$ & $\sqrt{ }$ & $\sqrt{ }$ & $\sqrt{ }$ & \\
\hline Panicum scribnerianum. . . & $\sqrt{ }$ & $\sqrt{ }$ & $\sqrt{ }$ & $\sqrt{ }$ & $\sqrt{ }$ & Lespedeza capitata. . . & $\sqrt{ }$ & $\cdots$ & $\ldots$ & $\sqrt{ }$ & . \\
\hline P. wilcoxianum . . . . . . . . & $\sqrt{ }$ & $\sqrt{ }$ & $\sqrt{ }$ & $\sqrt{ }$ & $\sqrt{ }$ & Liatris pycnostachya. & $\sqrt{ }$ & $\sqrt{ }$ & & & \\
\hline Poa pratensis.......... & $\sqrt{ }$ & $\sqrt{ }$ & $\sqrt{ }$ & $\sqrt{ }$ & $\sqrt{ }$ & L. scariosa. . . . . . . & $\sqrt{ }$ & & & $\sqrt{ }$ & \\
\hline Sorghastrum nutans. . & $\sqrt{ }$ & $\sqrt{ }$ & $\sqrt{ }$ & $\sqrt{ }$ & $\sqrt{ }$ & L. squarrosa . . . . & $\sqrt{ }$ & $\sqrt{ }$ & $\sqrt{ }$ & & \\
\hline Sporobolus heterolepis. . . . & $\sqrt{ }$ & $\sqrt{ }$ & $\sqrt{ }$ & $\cdots$ & & Linum sulcatum......... & $\sqrt{ }$ & $\ldots$ & $\sqrt{ }$ & $\sqrt{ }$ & $\sqrt{ }$ \\
\hline Stipa spartea........... & $\sqrt{ }$ & $\sqrt{ }$ & $\sqrt{ }$ & $\sqrt{ }$ & $\sqrt{ }$ & Lithospermum linearifoli- & & & & & \\
\hline & & & & & & $\mathrm{um}_{\ldots} \ldots \ldots \ldots \ldots \ldots$ & $\sqrt{ }$ & $\sqrt{ }$ & & $\sqrt{ }$ & \\
\hline Acer & $\sqrt{ }$ & $\sqrt{ }$ & $\sqrt{ }$ & $\sqrt{ }$ & $\sqrt{ }$ & Lygodesmia juncea....... & $\sqrt{ }$ & & & $\sqrt{ }$ & $\sqrt{ }$ \\
\hline Achillea occidentalis. . . . . & $\sqrt{ }$ & & $\sqrt{ }$ & $\sqrt{ }$ & $\sqrt{ }$ & Meibomia canadensis. & . & $\sqrt{ }$ & & . & \\
\hline Amorpha canescens...... & $\sqrt{ }$ & $\sqrt{ }$ & $\sqrt{ }$ & $\sqrt{ }$ & $\sqrt{ }$ & M. illinoensis . . . . . . . & $\sqrt{ }$ & $\sqrt{ }$ & & $\sqrt{ }$ & $\sqrt{ }$ \\
\hline Anemone cylindrica ....... & $\sqrt{ }$ & & $\sqrt{ }$ & $\sqrt{ }$ & & Mesadenia tuberosa ....... & . & $\cdots$ & $\sqrt{ }$ & . & . \\
\hline Antennaria campestris... & $\sqrt{ }$ & $\sqrt{ }$ & $\sqrt{ }$ & $\sqrt{ }$ & $\sqrt{ }$ & Onosmodium occidentale. . & . . & . . & . & $\sqrt{ }$ & \\
\hline Artemisia gnaphalodes. . . & $\ldots$ & $\sqrt{ }$ & & $\ldots$ & & Oxalis stricta . . . . . . . & $\sqrt{ }$ & & & & $\sqrt{ }$ \\
\hline Asclepias tuberosa.... & & $\sqrt{ }$ & $\sqrt{ }$ & & $\sqrt{ }$ & Pedicularis canadensis..... & . & $\sqrt{ }$ & $\sqrt{ }$ & & \\
\hline A. verticillata...... & $\sqrt{ }$ & $\ldots$ & . & $\sqrt{ }$ & $\sqrt{ }$ & Petalostemon candidus.... & $\sqrt{ }$ & $\sqrt{ }$ & $\sqrt{ }$ & $\sqrt{ }$ & $\sqrt{ }$ \\
\hline Aster azureus. . & $\cdots$ & & . & $\ldots$ & $\sqrt{ }$ & P. purpureus........ & $\sqrt{ }$ & . & $\cdots$ & $\sqrt{ }$ & $\sqrt{ }$ \\
\hline A. laevis..... & $\sqrt{ }$ & & $\sqrt{ }$ & $\sqrt{ }$ & $\sqrt{ }$ & Phlox pilosa . . . . . . & . . & $\sqrt{ }$ & $\sqrt{ }$ & . . & $\sqrt{ }$ \\
\hline A. multiflorus. . & $\sqrt{ }$ & $\sqrt{ }$ & $\sqrt{ }$ & $\sqrt{ }$ & $\sqrt{ }$ & Physalis lanceolata. & $\sqrt{ }$ & $\sqrt{ }$ & $\sqrt{ }$ & $\sqrt{ }$ & $\sqrt{ }$ \\
\hline A. oblongifolius . & & 10 & $\ldots$ & $\ldots$ & $\sqrt{ }$ & Psoralea argophylla. & $\ldots$ & $\sqrt{ }$ & $\sqrt{ }$ & . . & . \\
\hline gittifolius. . & $\sqrt{ }$ & & $\sqrt{ }$ & $\sqrt{ }$ & $\sqrt{ }$ & P. esculenta....... & $\sqrt{ }$ & & . & $\sqrt{ }$ & \\
\hline A. sericeus........ & $\sqrt{ }$ & $\sqrt{ }$ & $\sqrt{ }$ & $\sqrt{ }$ & $\sqrt{ }$ & Rosa arkansana. . & $\sqrt{ }$ & $\sqrt{ }$ & $\sqrt{ }$ & $\sqrt{ }$ & $\sqrt{ }$ \\
\hline alus canadensi & $\ldots$ & $\sqrt{ }$ & $\cdots$ & .. & . & Senecio plattensis... . . . & $\sqrt{ }$ & $\sqrt{ }$ & $\sqrt{ }$ & $\sqrt{ }$ & $\sqrt{ }$ \\
\hline Baptisia leucophaea & $\ldots$ & $\sqrt{ }$ & $\sqrt{ }$ & & & Silphium integrifolium . & . . & .. & $\sqrt{ }$ & & . \\
\hline Ceanothus pubescens.... & $\sqrt{ }$ & $\sqrt{ }$ & $\sqrt{ }$ & $\sqrt{ }$ & $\sqrt{ }$ & S. laciniatum . . . . . . . & $\sqrt{ }$ & & $\sqrt{ }$ & $\sqrt{ }$ & \\
\hline ecrista fasciculata. & $\sqrt{ }$ & $\sqrt{ }$ & & & & Sisyrinchium angustifolium & $\sqrt{ }$ & & $\sqrt{ }$ & $\cdots$ & $\sqrt{ }$ \\
\hline indra umbellata. & $\sqrt{ }$ & $\sqrt{ }$ & $\sqrt{ }$ & & $\sqrt{ }$ & Solidago glaberrima....... & 18 & $\sqrt{ }$ & $\sqrt{ }$ & $\sqrt{ }$ & . \\
\hline sis palmata....... & $\sqrt{ }$ & $\sqrt{ }$ & . & $\sqrt{ }$ & $\sqrt{ }$ & S. rigida $\ldots \ldots \ldots \ldots$ & $\sqrt{ }$ & $\sqrt{ }$ & $\sqrt{ }$ & $\sqrt{ }$ & \\
\hline Drymocallis agrimonioides. & $\sqrt{ }$ & $\sqrt{ }$ & & $\sqrt{ }$ & $\sqrt{ }$ & S. rigidiuscula.... & $\sqrt{ }$ & $\sqrt{ }$ & $\ldots$ & & $\sqrt{ }$ \\
\hline Echinacea pallida... & $\sqrt{ }$ & $\sqrt{ }$ & $\sqrt{ }$ & $\sqrt{ }$ & $\sqrt{ }$ & Vernonia baldwini. & $\sqrt{ }$ & $\sqrt{ }$ & $\sqrt{ }$ & $\sqrt{ }$ & $\sqrt{ }$ \\
\hline Equisetum laevigatum & $\sqrt{ }$ & $\sqrt{ }$ & & $\sqrt{ }$ & & Viola papilionacea. & $\sqrt{ }$ & $\cdots$ & $\sqrt{ }$ & $\cdots$ & $\cdots$ \\
\hline Erigeron ramosus.... & $\sqrt{ }$ & $\sqrt{ }$ & $\sqrt{ }$ & $\sqrt{ }$ & $\sqrt{ }$ & V. pedatifida . . . . . & $\sqrt{ }$ & $\sqrt{ }$ & $\sqrt{ }$ & $\sqrt{ }$ & \\
\hline Eryngium yucci & $\sqrt{ }$ & $\sqrt{ }$ & $\sqrt{ }$ & $\ldots$ & $\cdots$ & Zizia aurea . . . . . . & & $\sqrt{ }$ & $\sqrt{ }$ & $\cdots$ & $\cdots$ \\
\hline
\end{tabular}


canadensis, because of drought, and Muhlenbergia cuspidata, a xeric species not thickly distributed in the prairies). Reduction at the third group of stations to nine included the loss of six species by drought (Andropogon scoparius, Carex festucacea, Panicum scribneri-

TABLE 2

BLUESTEM PRAIRIES IN NEBRASKA AND KANSAS, SHOWING SPECIES OF PLANTS OCCURRING AT EACH SAMPLING STATION: I, LINCOLN; 2, NELSON;

3, Hebron; AND 4, BeLleville

\begin{tabular}{|c|c|c|c|c|c|c|c|c|c|}
\hline \multirow{2}{*}{ Specres } & \multicolumn{4}{|c|}{ Stations } & \multirow{2}{*}{ Species } & \multicolumn{4}{|c|}{ Stations } \\
\hline & I & 2 & 3 & 4 & & I & 2 & 3 & 4 \\
\hline 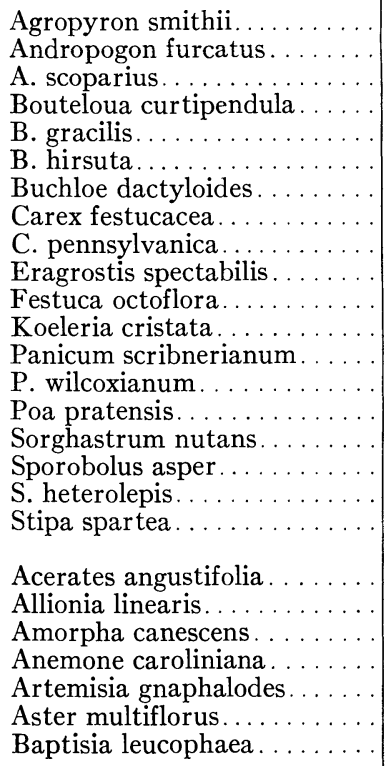 & $\begin{array}{l}\sqrt{ } \\
\sqrt{ } \\
\sqrt{ } \\
\cdots \\
\cdots \\
\cdots \\
\sqrt{ } \\
\cdots \\
\sqrt{ } \\
\sqrt{ } \\
\sqrt{ } \\
\sqrt{ } \\
\sqrt{ } \\
\sqrt{ } \\
\sqrt{ } \\
\cdots \\
\sqrt{ } \\
\cdots \\
\sqrt{ } \\
\sqrt{ }\end{array}$ & $\begin{array}{l}\cdots \\
\sqrt{ } \\
\sqrt{ } \\
\sqrt{ } \\
\sqrt{ } \\
\sqrt{ } \\
\sqrt{ } \\
\sqrt{ } \\
\cdots \\
\sqrt{ } \\
\sqrt{ } \\
\cdots \\
\cdots \\
\cdots \\
\cdots \\
\cdots \\
\cdots \\
\cdots \\
\cdots \\
\sqrt{ } \\
\sqrt{ } \\
\sqrt{ } \\
\cdots\end{array}$ & 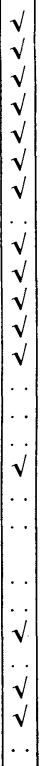 & $\begin{array}{l}\ldots \\
\sqrt{ } \\
\sqrt{ } \\
\sqrt{ } \\
\sqrt{ } \\
\sqrt{ } \\
\sqrt{ } \\
\sqrt{ } \\
\sqrt{ } \\
\sqrt{ } \\
\cdots \\
\sqrt{ } \\
\cdots \\
\ldots \\
\ldots \\
\cdots \\
\sqrt{ } \\
\ldots \\
\cdots \\
\cdots \\
\sqrt{ } \\
\sqrt{ } \\
\ldots \\
\sqrt{ } \\
\sqrt{ }\end{array}$ & 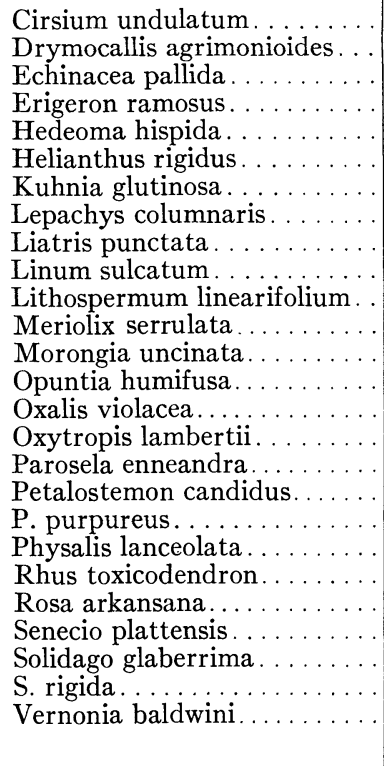 & $\begin{array}{l}\sqrt{ } \\
\sqrt{ } \\
\sqrt{ } \\
\sqrt{ } \\
\sqrt{ } \\
j \\
\sqrt{ } \\
\sqrt{ } \\
\sqrt{ } \\
\cdots \\
\cdots \\
\cdots \\
\cdots \\
\sqrt{ } \\
2 \\
\sqrt{ } \\
\cdots \\
\sqrt{ } \\
\sqrt{ } \\
\sqrt{ } \\
\cdots\end{array}$ & 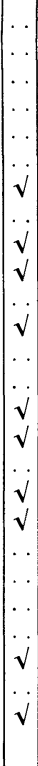 & 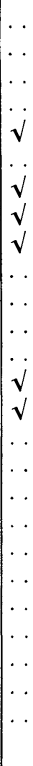 & 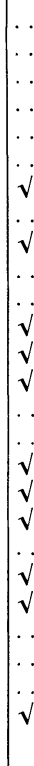 \\
\hline
\end{tabular}

anum, P. wilcoxianum, Poa pratensis, and Sorghastrum nutans). Bouteloua hirsuta, Eragrostis spectabilis, and Sporobolus heterolepis formerly occurred, if at all, only sparingly. No new species were gained. A final reduction to only four grasses at the western Kansas stations resulted from death of all the mid grasses which formerly occurred there except Bouteloua curtipendula. 
Among the grasses, B. curtipendula alone was found at all four groups of stations, thus illustrating its wide adaptability and droughtresistant qualities. Conversely, Stipa spartea occurred only at the first two, but the deeply rooted Andropogon furcatus and the rapidly reproducing Koeleria cristata at all but the last. Buchloe dactyloides and Bouteloua gracilis, most xeric of all, occurred at all three western

TABLE 3

WHEAT-GRASS PRAIRIES IN NEBRASKA AND KANSAS, SHOWING SPECIES OF PLANTS OCCURRING AT EACH SAMPLING STATION: I, ClAY CENTER; 2, CARleton; AND 3, Montrose

\begin{tabular}{|c|c|c|c|c|c|c|c|}
\hline \multirow{2}{*}{ Species } & \multicolumn{3}{|c|}{ Stations } & \multirow{2}{*}{ Species } & \multicolumn{3}{|c|}{ Stations } \\
\hline & $\mathbf{r}$ & 2 & 3 & & $\mathrm{I}$ & 2 & 3 \\
\hline 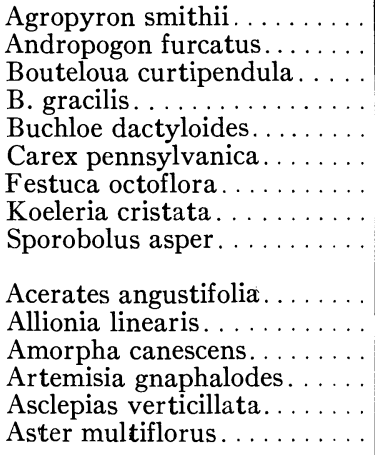 & $\begin{array}{l}\sqrt{ } \\
j \\
\sqrt{ } \\
j \\
\sqrt{ } \\
\sqrt{ } \\
. \\
\sqrt{ } \\
\sqrt{ } \\
\sqrt{ } \\
\sqrt{ }\end{array}$ & $\begin{array}{l}\sqrt{ } \\
\sqrt{ } \\
\sqrt{ } \\
\sqrt{ } \\
\sqrt{ } \\
\sqrt{ } \\
\sqrt{ } \\
\sqrt{ } \\
\sqrt{ }\end{array}$ & \begin{tabular}{l|l}
$\sqrt{ }$ \\
$\sqrt{ }$ \\
$\sqrt{ }$ \\
$\sqrt{ }$ \\
$\sqrt{ }$ \\
$\sqrt{ }$ \\
$\cdots$ \\
$\cdots$ \\
$\cdots$ \\
$\sqrt{ }$ \\
$\sqrt{ }$ \\
$\sqrt{ }$ \\
$\cdots$ \\
$\cdots$ \\
$\sqrt{ }$
\end{tabular} & 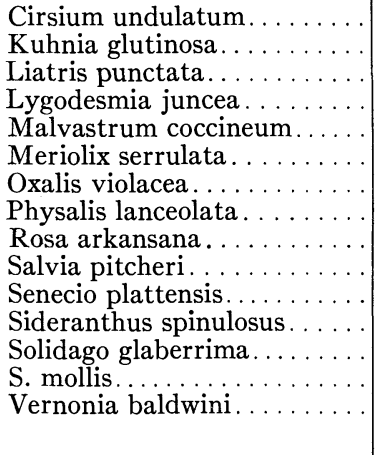 & \begin{tabular}{l|l}
$\sqrt{ }$ \\
$\sqrt{ }$ \\
$\sqrt{ }$ \\
$\sqrt{ }$ \\
$\sqrt{ }$ \\
$\sqrt{ }$ \\
$\sqrt{ }$ \\
$\cdots$ \\
$\cdots$ \\
$\cdots$ \\
$\sqrt{ }$ \\
$\cdots$ \\
$\sqrt{ }$ \\
$\sqrt{ }$ \\
$\cdots$
\end{tabular} & $\begin{array}{l}\cdots \\
j \\
\sqrt{ } \\
\cdots \\
\cdots \\
j \\
\sqrt{ } \\
\cdots \\
j \\
\cdots \\
\cdots \\
\cdots \\
\cdots \\
\cdots \\
\cdots\end{array}$ & 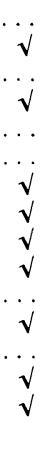 \\
\hline
\end{tabular}

groups of stations; in fact, they are rapidly spreading to replace mid grasses.

Reduction of forbs from sixty-five in Iowa to thirty-three in the Lincoln group occurred notwithstanding the gain of a total of nine species, including the xeric Allionia linearis, Cirsium undulatum, Opuntia humifusa, and Oxytropis lambertii. The further reduction to twenty-one species was accompanied by the addition of three western ones-Malvastrum coccineum, Sideranthus spinulosus, and Solidago mollis. The final group of only eleven perennial forbs includes two xeric species (Psoralea tenuiflora and Allium nuttallii) not found in the preceding sampling areas. 

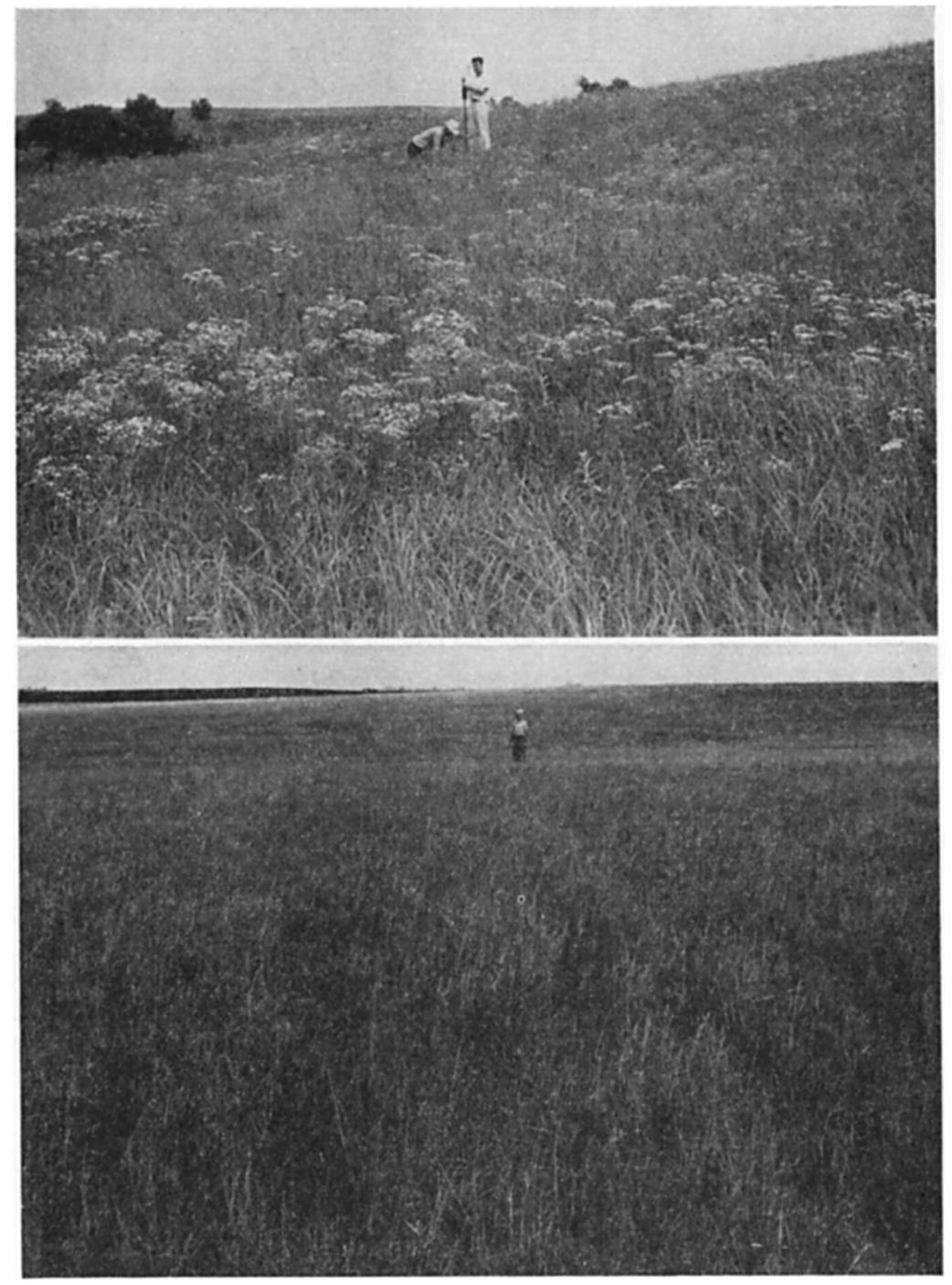

FIGS. 14, I5.-Fig. 14 (above), prairie at Anita, Iowa, August 15, 1939, showing abundance of forbs, most conspicuous of which is Euphorbia corollata. Fig. I 5 (below), prairie near Lincoln, Nebraska, August I, I939, showing almost entire absence of forbs, typical of conditions at all but the Iowa stations. 

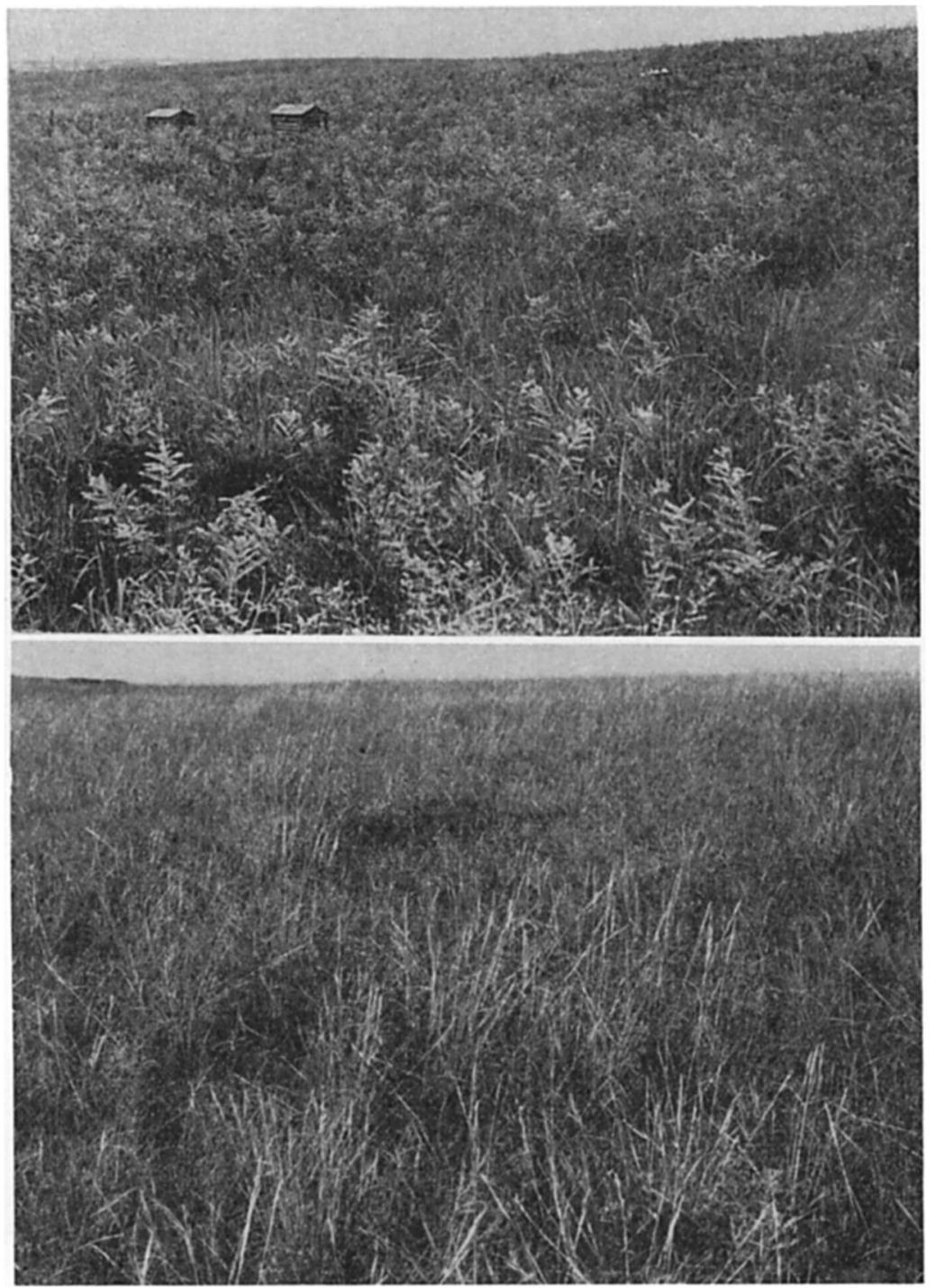

Figs. 16, 17.-Fig. I6 (above), portion of Belmont prairie at Lincoln, July 6, I932, showing abundance of Amorpha canescens and other forbs in cover of Andropogon scoparius. Fig. 17 (below), same area on July 6, 1939. Note great decrease in forbs and replacement of little bluestem by Stipa spartea and other more xeric grasses. 
Six species of the ground layer or understory occurred only at the most mesic group of stations, although they were formerly plentiful in the Lincoln group also, some species being common even farther westward. These are Antennaria campestris, Sisyrinchium angustifolium, Viola pedatifida, V. papilionacea, Fragaria virginiana, and the rosettes of Hieracium longipilum. Clearly this depletion of the ground layer was an effect of drought. Three other understory species (Carex pennsylvanica, Oxalis violacea, and Anemone caroliniana) not only persisted but increased in abundance, probably because of underground storage organs (4).

A number of very deeply rooted species occurred at all but the most xeric group of stations. These were Amorpha canescens, Rosa arkansana, Vernonia baldwini, Solidago glaberrima, and Aster multiflorus. Senecio plattensis and Artemisia gnaphalodes accompanied them. Kuhnia glutinosa, which is very drought resistant, probably because of its excellent, deeply seated taproot, was the only species found at all four station-groups. In fact, it occurred at each of eleven stations, although never abundantly. Other species found at the three more xeric groups of stations, and which are notably drought resistant, are Liatris punctata, Cirsium undulatum, Allionia linearis, and (absent in the Lincoln group) Lygodesmia juncea. The equally xeric Malvastrum coccineum and Sideranthus spinulosus, found only at the two driest station-groups, are not naturally distributed so far eastward as the preceding.

It is of interest and importance that of the eleven Leguminosae in Iowa, the number was reduced first to seven, and then to one at each of the more westerly station-groups. The much more regular occurrence of many species at all the stations in the Iowa group, unaffected by drought, is also significant. Of the total of fifteen grasses or grasslike species, thirteen were found at each station, but only ten to thirteen of a total of nineteen at each station of the Lincoln group.

These data, presented from the relatively small but numerous sampling areas, are in general substantiated by much more extensive surveys, including entire prairies, which are now under way. They indicate clearly some of the drastic changes in plant populations resulting from the years of drought. A loss of 50-66 per cent 
of forbs was found in 1938; during 1939 they have been further depleted both in numbers and species.

The value of this study of environmental relations, density of plant cover, distribution of forbs, etc.-although done intensively only in this central area of the mid-continental grasslands-is enhanced by the fact that it represents generally the great changes that have been wrought in the grasslands from east to west by the several years of drought.

\section{Summary}

I. Four groups of prairies of known previous history, extending from southwestern Iowa to western Kansas, were studied in I939.

2. The Iowa group (precipitation about 32 inches) had been scarcely affected by the great drought. At one Nebraska-Kansas group, bluestem grasses (Andropogon spp.) still prevailed; at the other they had died and been replaced by Agropyron smithii. Bouteloua gracilis and Buchloe dactyloides were the chief grasses of the western Kansas prairies (precipitation about 22 inches).

3. The twelve prairies in the four groups all occurred on deep, fertile, silt-loam soils; water content was determined monthly to a depth of 6 feet.

4. The bluestem prairies of Iowa, where rainfall was plentiful, had a continuous supply of available water at all depths; those of Nebraska and Kansas had only a low supply after early spring and were repeatedly threatened with drought. In the wheat-grass group, available deep-soil moisture was the exception, and repeated exhaustion of surface soil moisture occurred. Water was available only in the surface soil at the short-grass stations and at only two or three periods.

5. Slightly higher temperatures, 50-100 per cent more evaporation, and two to three times as much wind movement occurred in western Kansas as in eastern Nebraska.

6. No previous deterioration of vegetation had occurred in Iowa. The ground layer had been destroyed and the basal area was only one-half to two-thirds normal in the drought-depleted bluestem prairies westward. Drought and dust had destroyed most of the former plant cover of the third group of prairies, which were now 
dominated by an open growth of western wheat grass which permitted a continuous pattern of bare soil. In western Kansas the 85 per cent basal cover of short grasses had been reduced by continued drought, burial by dust, and injury by grasshoppers to IO-I 5 per cent. The remaining soil was bare.

7. Grasses grew normally in Iowa, reaching a foliage level of 18 inches; they dried after midsummer and failed to flower in eastern Nebraska. Wheat grass dried very early and burned readily in July. The short grasses in west-central Kansas were dormant during most of the summer but grew to a height of 3 inches when revived by late summer showers.

8. In Iowa, fifteen species of grasses and sedges occurred at the sampling stations, but nineteen at the western, bluestem stationgroup. There were but nine at the wheat-grass stations and only four in the short-grass areas.

9. Native forbs similarly decreased from sixty-five to thirty-three species, then to twenty-one, and finally to eleven.

Io. Conditions of the central area of the mid-continental grassland reveal in general changes that have been wrought elsewhere from east to west by continued drought.

UNIVERSITY OF NEBRASKa

LINCOLN, NEBRASKA

Fort Hays Kansas State College

Hays, Kansas

\section{LITERATURE CITED}

r. Albertson, F. W., Ecology of mixed prairie in west central Kansas. Ecol. Monog. 7:48I-547. I937.

2. Robertson, J. H., A quantitative study of true-prairie vegetation after three years of extreme drought. Ecol. Monog. 9:43I-492. I939.

3. Weaver, J. E., and Albertson, F. W., Effects of the great drought on the prairies of Iowa, Nebraska, and Kansas. Ecology 17:567-639. 1936.

4. Weaver, J. E., and Albertson, F. W., Major changes in grassland as a result of continued drought. Вот. GAZ. I00:576-59I. I939.

5. Weaver, J. E., and Fitzpatrick, T. J., The prairie. Ecol. Monog. 4:109295. I934.

6. Weaver, J. E., Stoddart, L. A., and Noll, W., Response of the prairie to the great drought of I934. Ecology 16:61 2-629. I935. 